\title{
Congenital Splenic Hypoplasia in an Elderly Patient
}

\author{
Kasumi Satoh, Shigeharu Ueki, Ayumi Omokawa and Makoto Hirokawa
}

Key words: Howell-Jolly body, neutrophilia, Pappenheimer body, splenic hypoplasia

(Intern Med 55: 1819-1820, 2016)

(DOI: 10.2169/internalmedicine.55.6355)

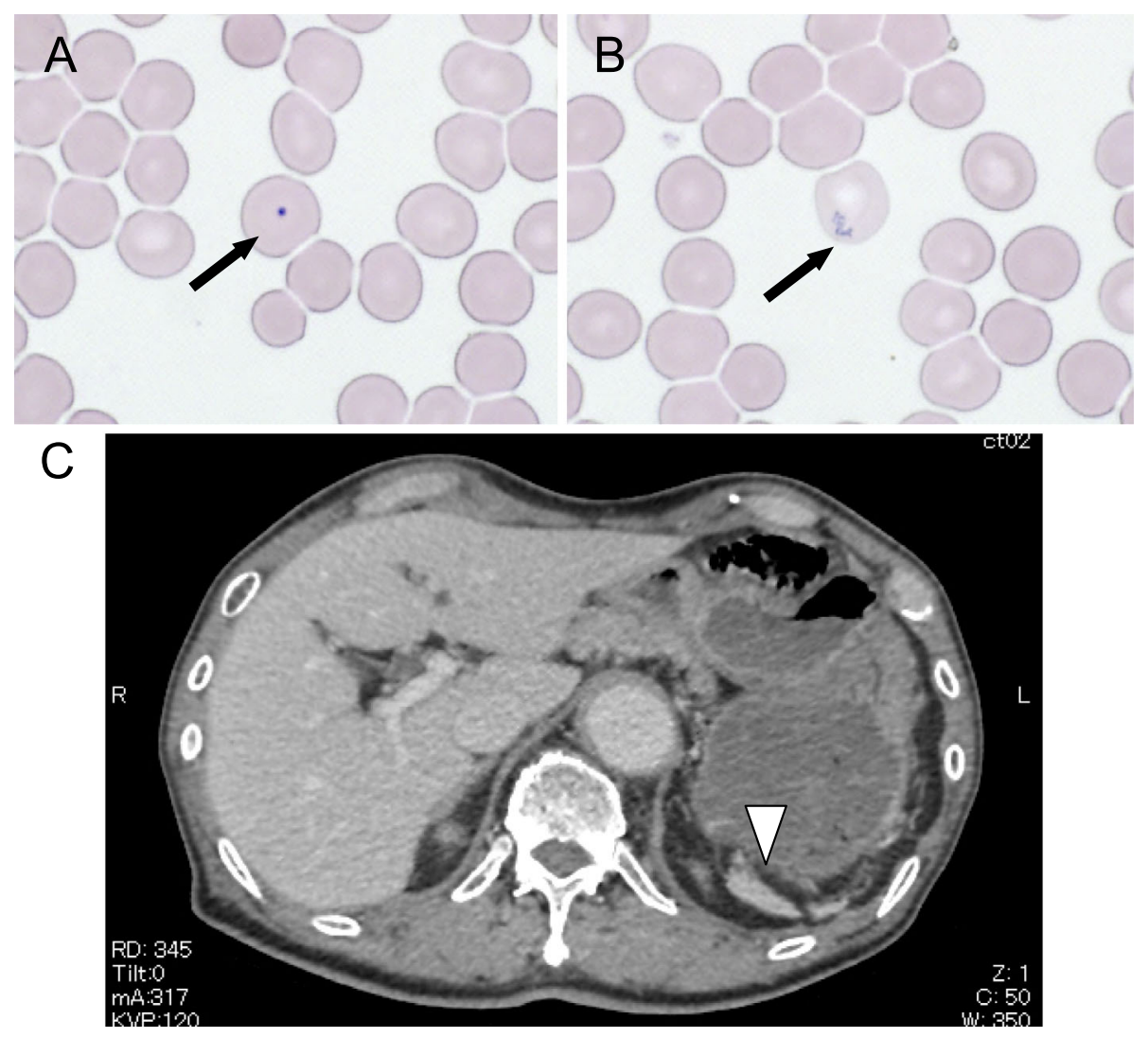

Picture.

An 86-year-old man visited our hospital complaining of persistent epigastric discomfort. This patient had no relevant medical history. The patient's vital signs and the results of physical and laboratory examinations were normal aside from a high white blood cell (WBC) count. The epigastric symptom spontaneously remitted, however, the neutrophilia (WBC count:14,100/ $\mu \mathrm{L}$, with $91.3 \%$ neutrophil) remained. A blood smear revealed the presence of Howell-Jolly bodies (Picture A, arrow) and Pappenheimer bodies (Picture B, arrow), suggesting hyposplenism (1). Abdominal $\mathrm{CT}$ revealed splenic hypoplasia (Picture C, arrowhead). On the basis of the above findings, the patient was diagnosed with congenital splenic hypoplasia. Hyposplenic patients are at risk of severe sepsis caused by encapsulated bacteria (commonly $S$. pneumoniae). Overwhilming post splenectomy infection (OPSI) increases the mortality rate to $70 \%$; the life time risk of developing OPSI is estimated to be 5\% (2). It is recommended that physicians carefully review the peripheral blood smear result in patients with neutrophilia who lack significant clinical symptoms. Preventation measures, such as vaccination, are also considerd to be important and beneficial. 
Intern Med 55: 1819-1820, 2016 DOI: 10.2169/internalmedicine.55.6355

The authors state that they have no Conflict of Interest (COI).

\section{References}

1. Steinberg MH, Gatling RR, Tavassoli M. Evidence of hyposplen- ism in the presence of splenomegaly. Scand J Haematol 31: 437439, 1983.

2. de Porto AP, Lammers AJ, Bennink RJ, ten Berge IJ, Speelman P, Hoekstra JB. Assessment of splenic function. Eur J ClinMicrobiol Infect Dis 29: 1465-1473, 2010.

(C) 2016 The Japanese Society of Internal Medicine http://www.naika.or.jp/imonline/index.html 